\title{
IDENTIFYING PROGNOSTIC FACTORS WHICH AFFECT THE SUCCESS OF ECTOPIC PREGNANCY TREATMENT WITH A SINGLE DOSE METHOTREXATE
}

\author{
Berna Sermin KILIC, Abdullah TUTEN, Mahmut ONCUL, Abdullah Serdar ACIKGOZ, Pelin Kutsiye OCAL
}

Department of Obstetrics and Gynecology, Istanbul University Medical Faculty, Istanbul

\begin{abstract}
SUMMARY
Objective: To identify prognostic factors which affect the success of ectopic pregnancy treatment with a single dose methotrexate

Material and methods: 99 patients whom applied to Cerrahpaşa Medical Faculty Obstetrics and Gynecology Department, between year 2000 and 2010 treated with single-dose methotrexate were divided into two subgroups; successful and unsuccessful. Likely to affect the success of the demographic clinical and laboratory findings were compared retrospectively.

Results: Single-dose methotrexate therapy has been successful in 67 patients (67.6\%). In the unsuccessful group, serum $\beta$ - hCG values were significantly higher than successful group. (successful group median $\beta$-hCG value: 819 (122-3822) $\mathrm{mIU} / \mathrm{ml}$, Unsuccessful group median $\beta$ - hCG value: 3562 (642-18000) $\mathrm{mIU} / \mathrm{ml}, \mathrm{p}<0.001)$.

Conclusion: Single-dose methotrexate therapy is effective in the initial treatment of ectopic pregnancy. It is observed that the main prognostic factor affecting the failure is elevated levels of $\beta-h C G$.
\end{abstract}

Key words: ectopic pregnancy, single-dose methotrexate therapy, $\beta-h C G$

Journal of Turkish Society of Obstetrics and Gynecology, (J Turk Soc Obstet Gynecol), 2014; Vol: 11, Issue: Pages:

\section{TEK DOZ METOTREKSAT ILE EKTOPIK GEBELIKK TEDAVISINIIN BAŞARISINI ETKILEYEN PROGNOSTIK FAKTÖRLERİN BELIRLENMESI}

\section{ÖZET}

Amaç: Tek doz metotreksat ile ektopik gebelik tedavisinin başarısını etkileyen prognostik faktörleri belirlemek. Gereç ve yöntemler: 2000 ile 2010 yılları arasında Cerrahpaşa Tıp Fakültesine başvurup tek doz metotreksat tedavisi alan 99 hasta başarılı olan ve olmayan diye iki alt gruba ayrıldı. Başarıyı etkileyebilecek olası demografik, klinik ve laboratuvar bulguları retrospektif olarak karşılaştırıldı.

Bulgular: Tek doz metotreksat tedavisi 67 (\% 67.6) hastada başarılı olmuştur. Başarısız olan grupta serum $\beta$-hCG değerleri başarllı olan gruba göre anlamlı olarak yüksek bulunmuştur (başarılı olan grup medyan $\beta$-hCG değeri: 819 (122-3822 mIU/ml, başarısız olan grup medyan $\beta$-hCG değeri: 3562 (642-18000) mIU/ml, p<0,001).

Sonuç: Tek doz metotreksat tedavisi ektopik gebeliğin başlangıç tedavisinde etkili bir yöntemdir. Tedavinin başarısızliğını etkileyen ana prognostik faktör olarak $\beta-h C G$ değerinin yüksekliği gözükmektedir.

Anahtar kelimeler: ektopik gebelik, tek doz metotreksat tedavisi, $\beta-h C G$

Türk Jinekoloji ve Obstetrik Derneği Dergisi, (J Turk Soc Obstet Gynecol), 2014; Cilt: 11, Sayl: Sayfa:

Address for Correspondence: Dr. Pelin Kutsiye Öcal. Cerrahpaşa Tıp Fakültesi Kadın Hastalıkları ve Doğum Anabilim Dalı, İstanbul Phone: +90(532) 5760080 e-mail: drpelinocal@hotmail.com

Received: 22. November 2013, revised: 21 December 2013, accepted: 25 December 2013, online publication: 26 December 2013 


\section{INTRODUCTION}

The incidence of ectopic pregnancy has been increasing in developed countries ${ }^{(1)}$. However, the possibility of early detection has significantly decreased disease related morbidity and mortality. In the treatment of disease process, there has been a shift from surgery to medical therapy ${ }^{(2)}$. Medical treatment of ectopic pregnancy with methotrexate was applied first time in 1982 by Tanaka et al. and in the following period, medical treatment in the treatment of ectopic pregnancy without the risks associated with surgery was safe and effective ${ }^{(3)}$. Although there is a very high treatment failure, it may be tubal rupture after a few days of treatment. Despite the effectiveness of treatment, success rates ranged from $64.0 \%$ to $94.2 \%$. This situation makes it important to determine factors affecting the success of medical treatment of ectopic pregnancy $(4-6)$.

The purpose of this study is to investigate the prognostic factors affecting the success on patients diagnosed ectopic pregnancy and treated medically single-dose methotrexate during a ten-year period in our clinic.

\section{MATERIALS AND METHODS}

In Istanbul University Cerrahpaşa Medical Faculty Obstetrics and Gynecology Department, retrospectively, between January 2000 - January 2010, a total of 222 patients diagnosed and treated ectopic pregnancy were subjected to evaluation. Such cases; age, gravida, pariete, abortus and curettage number, method of contraception, previous ectopic pregnancy, tubal sterilization history, initial $\beta-h C G$ value, ultrasonographic findings and treatment regimens were recorded by examination of patient files and operative reports. 121 patients who preferred surgery as initial treatment were excluded from the study. Scheduled to receive a single dose methotrexate therapy, hemodynamically stable, without evidence of rupture and transvaginal ultrasonography of fetal cardiac activity 101 patients with ectopic pregnancies were included in the study.

Methotrexate was performed in the absence of methotrexate allergy, liver, lung, kidney, hematological diseases. In order to determine this, blood groups, complete blood count, liver function tests, blood urea nitrogen and creatinine levels were measured for all patients. Patients with a history of lung disease was assessed by chest X-ray due to the risk of methotrexate interstitial pneumonitis. For failing to adhere to this criterion, one of two patients, methotrexate were not applied, had liver enzyme elevation, while the number of platelets was below 100,000 in the other patient. For the Methotrexate treatment, patients acknowledged the informed consent form. Patients suitable for methotrexate treatment were treated $50 \mathrm{mg} / \mathrm{m}^{2}$ single dose of methotrexate IM. Rh immunoglobulin was performed to patients with $\mathrm{Rh}$ incompatibility. The day Methotrexate dose applied was considered as day 1 . Between day 4 and day 7 of treatment, $\beta$-hCG falling more than $15 \%$ in value, patients were followed up three times until $<5 \mathrm{miu} / \mathrm{ml}$ and these patients were considered patients with adequate single dose methotrexate. However, between day 4 and day 7 of treatment, $\beta$-hCG falling less than $15 \%$ in value and hemodynamic instability in developing patients were considered patients with inadequate single dose methotrexate. Hemodynamic instability; following-up after single-dose methotrexate therapy, suggestive of intrabdominal rupture and hemorrhage, chronic decline in hematocrit follow-up series accompanying tachycardia and hypotension were considered the development of acute abdominal findings. Repeated doses of methotrexate or surgery was performed to patients single-dose methotrexate therapy was failed.

As initial therapy, 99 patients with hemodynamically stable methotrexate therapy area were divided into two groups.

Group 1: Initially taking methotrexate therapy and medical treatment was successful.

Group 2: Initially taking methotrexate therapy and medical treatment was failed.

For these groups, age, gravidity, parity, abortion, curretage, ectopic pregnancy, conceive shape, Intrauterine device presence, pelvic inflammatory disease, previous history of surgery admission $\beta-\mathrm{hCG}$ level, and ectopic pregnancy ultrasound findings were compared retrospectively.

Statistical analyses were performed using the Statistical Package for the Social Sciences (SPSS) Software, version 18.0. The Shapiro Wilk test and KolmogorovSmirnov test of normality were performed to choose the appropriate statistical test. Continuous variables were be given as mean \pm standard deviation if normally distributed, and as median (interquartile range) if not 
normally distributed. If the normality assumption for the comparison of means between two groups was satisfied, Student's t-test was used for the comparisons of means. Alternatively, if there was evidence of nonnormality the Mann-Whitney $U$ test was used. Comparisons between proportions were performed with a Pearson's chi-squared test or Fisher's exact test. Differences among groups were considered to be significant if the $\mathrm{P}$ value was $<0.05$.

\section{RESULTS}

A total of 222 patients diagnosed and treated ectopic pregnancy were subjected to evaluation between January 2000 - January 2010. As initial therapy, 99 patients were treated with a single dose of methotrexate. The average age of patients was $30.72 \pm 5.76$, at the time of diagnosis of gestational week was $6.7 \pm 1.0$ weeks, ectopic pregnancy size was $22.07 \pm 13.32 \mathrm{~mm}$, serum ß-hCG level was $2196 \pm 2603$ mIU/ml (Table I). While single-dose methotrexate therapy was successful in 67 (\% 67.6) patients, it was unsuccessful 32 in $(32.3 \%)$ patients. Single-dose methotrexate for patients' (with and without success) demographic, clinical and laboratory features are shown in Table II. Between the groups, no difference was observed in terms of age, parity, abortion, hospital admission weeks of pregnancy, ectopic pregnancy size. However, in the second group, serum $\beta$-hCG values were significantly higher than the first group (The first group of median ß-hCG value: 819 (122-3822) $\mathrm{mIU} / \mathrm{mL}$, the second group of median $\beta-h C G$ value 3562 (642-18000) mIU $/ \mathrm{mL}, \mathrm{p}<0.001$ ), also median gravidity and curretage values were significantly higher than the first group. The risk factors for ectopic pregnancy were compared for first and second groups at Table III. There was no difference in terms of the parameters measured.

Table I: Single-dose methotrexate-treated patients' demographic, clinical and laboratory features.

\begin{tabular}{ll}
\hline & $\begin{array}{l}\text { Single-dose methotrexate- } \\
\text { treated patients } \\
(\mathbf{n = 9 9 )}\end{array}$ \\
\hline Age (years) & $30.72 \pm 5.76$ \\
Gravidity (n) & $1.8 \pm 1.9$ \\
Parity (n) & $0.8 \pm 1.01$ \\
Abortion (n) & $0.38 \pm 0.84$ \\
Curettage (n) & $0.56 \pm 1.27$ \\
Hospital admission weeks & \\
of pregnancy (weeks) & $6.7 \pm 1.0$ \\
B-hCG(mIU/ml) & $2196 \pm 2603$ \\
ectopic pregnancy size & \\
before treatment (mm) & $22.07 \pm 13.32$ \\
\hline
\end{tabular}

Table III: Single-dose methotrexate therapy in patients' (with and without success) risk factors for ectopic pregnancy.

\begin{tabular}{llll}
\hline & Group & Group & p \\
& $\mathbf{1}$ & $\mathbf{2}$ & \\
\hline Ectopic pregnancy history (n/N,\%) & $2 / 67(\% 0.2)$ & $4 / 32(\% 12.5)$ & 0.063 \\
Use of intrauterine devices (n/N,\%) & $2 / 67(\% 0.2)$ & $1 / 32(\% 0.3)$ & 0.97 \\
PID history (n/N,\%) & $2 / 67(\% 0.2)$ & $1 / 32(0.3)$ & 0.97 \\
Ovulation Induction (n/N,\%) & $9 / 67(\% 13.4)$ & $3 / 32(\% 0.9)$ & 0.563 \\
Abdominal surgery history (n/N,\%) & $23 / 67(\% 34)$ & $12 / 32(\% 37)$ & 0.617 \\
\hline$P<0.05:$ significant & & &
\end{tabular}

Table II: Single-dose methotrexate for patients' (with and without success) demographic, clinical and laboratory features.

\begin{tabular}{|c|c|c|c|c|c|}
\hline & \multicolumn{2}{|c|}{ Group 1 (n:67) } & \multicolumn{3}{|c|}{ Group 2 (n:32) } \\
\hline & Mean \pm SD & $\begin{array}{l}\text { Median } \\
\text { (min-max) }\end{array}$ & Mean \pm SD & $\begin{array}{l}\text { Median } \\
\text { (min-max) }\end{array}$ & $\mathbf{p}$ \\
\hline Age (years) & $31.1 \pm 5.9$ & $31(19-44)$ & $29.8 \pm 5.2$ & $29.5(20-40)$ & 0.300 \\
\hline Gravidity (n) & $1.6 \pm 1.9$ & $1(0-10)$ & $2.3 \pm 1.8$ & $2(0-8)$ & 0.021 \\
\hline Parity (n) & $0.7 \pm 0.9$ & $0(0-4)$ & $1 \pm 1.1$ & $1(0-4)$ & 0.194 \\
\hline Abortion (n) & $0.4 \pm 0.8$ & $0(0-5)$ & $0.3 \pm 0.8$ & $0(0-4)$ & 0.605 \\
\hline Curettage (n) & $0.4 \pm 1.3$ & $0(0-9)$ & $0.8 \pm 1.0$ & $0.5(0-3)$ & 0.002 \\
\hline \multicolumn{6}{|l|}{ Hospital admission } \\
\hline \multicolumn{6}{|l|}{ weeks of pregnancy } \\
\hline (weeks) & $6.5 \pm 3.1$ & $7.5(0-11)$ & $6.9 \pm 3.2$ & $7.8(0-11)$ & 0.224 \\
\hline$ß-\mathrm{hCG}(\mathrm{mIU} / \mathrm{ml})$ & $1180 \pm 953$ & $819(122-3822)$ & $4394 \pm 3552$ & $3562(642-18000)$ & $<0.001$ \\
\hline \multicolumn{6}{|l|}{ Ectopic pregnancy size } \\
\hline before treatment $(\mathrm{mm})$ & $21.01 \pm 12.6$ & $18(4-70)$ & $24.1 \pm 14.5$ & $20(0-60)$ & 0.201 \\
\hline
\end{tabular}




\section{DISCUSSION}

Ectopic pregnancy is the leading cause of the first trimester maternal mortality and morbidity. Effective and safe medical treatment with Methotrexate decreased the incidence of surgical treatment ${ }^{(7)}$. However, medical treatment was not hundred percent successful and prognostic factors affecting the success is not clear. In our study, $\beta-$ hCG values for failure of a single dose of methotrexate use are higher than successful ones. Including ectopic foci size and the weeks of pregnancy, majority of the other parameters were not significantly different between the groups.

The use of single-dose methotrexate for ectopic pregnancy are in clinical use since the $1990 \mathrm{~s}(8,9)$. Success rates ranged from $64 \%$ to $94.2 \%(4,10-15)$. In our study, the success rate was consistent with success rates of different studies in the literature (67.7\%). Initial ß-hCG level was found $2196 \pm 2603 \mathrm{mIU} / \mathrm{ml} .9$ of 32 patients who failed were treated second dose methotrexate and 23 patients were treated surgically. In the study by Adali et al, single-dose methotrexate therapy was found to be successful 14 in 18 patients (\% 77.7). Initial $\beta$ - hCG level was determied as $2615 \pm 2064 \mathrm{mIU} / \mathrm{ml} .4$ patients underwent surgery after a failed single dose methotrexate therapy ${ }^{(16)}$. In the study by Turhan et al, same treatment was found to be successful 9 in 11 patients $(81.8 \%)$. Initial $\beta-$ hCG level was determied as $1664 \pm 1571 \mathrm{mIU} / \mathrm{ml}$. The second dose methotrexate treatment was needed for 2 patients $(18.2 \%)$ who failed ${ }^{(17)}$. In the study by Alk1ş et al, same treatment was found to be successful 81 in 98 patients $(82.7 \%)$ and rest of the failed 17 patients (\%17.3) underwent surgery. Initial $\beta-h C G$ level was determied as $1592 \pm 2613 \mathrm{mIU} / \mathrm{ml}^{(18)}$.

In patients with ectopic pregnancy, reports on prognostic factors to successful response to single-dose methotrexate therapy are limited. In two previous studies in a manner similar to ours, high serum B-hCG levels has been identified as a single prognostic factor $(6,19)$. while in the study by Kimiaei et al, on top of initial $\beta-h C G$ values, ectopic focus size was determined to be significant in determining the effectiveness of single-dose methotrexate therapy ${ }^{(20)}$. Also in some studies, in addition to the height of initial ß-hCG values, initial and after methotrexate, fourth day, value of the decline at the $\beta$-hCG level was the most important indicators in predicting success $(21,22)$. Moreover, in the study by Mungan et al, ectopic pregnancy implantation at tubo-uterine has been shown to be important to determine the success of single-dose methotrexate therapy in ectopic pregnancy. In 73 of the 98 patients (\%74.4), single-dose methotrexate therapy were found to be successful while patients were divided by periampullary and peri-isthmic implantation and a dramatic difference was observed. According to this, 77 of 84 (\%91.6) periampullary located ectopic pregnancy were succeed while 4 of 14 (28.5) ectopic pregnancy localized in the peri-isthmic were succeed(23).

As a result, single-dose methotrexate therapy are effectively used in the initial treatment of ectopic pregnancy. The main prognostic factor that affect the success of treatment appears to be the height of $\beta-\mathrm{hCG}$ values. In terms of other potential prognostic factors such as maternal age, gestational week and focus size of ectopic pregnancy, more studies are needed.

\section{REFERENCES}

1. Coste J, Bouyer J, Uguetto S, Gerbaud L,Fernandez H, Pouly $\mathrm{JL}$, et al. Ectopic pregnancy is again on the increase. Recent trends in the incidence of ectopic pregnancies in France (19922002). Hum Reprod 2004;19(9):2014-8.

2. Luciano AA, Roy G, Solima E. Ectopic pregnancy from surgical emergency to medical management. Ann N Y Acad Sci 2001;943:235-54.

3. Tanaka T, Hayashi H, Fujimoto S, Ichinoe K. Treatment of interstitial ectopic pregnancy with methotrexate: report of a successful case. Fertil Steril 1982;37(6):851-2.

4. Fernandez H, Lelaidier C, Thouvenez V, Frydman R. The use of a pretherapeutic, predictive score to determine inclusion criteria for the non-surgical treatment of ectopic pregnancy. Hum Reprod 1991;6(7):995-8.

5. Canis M, Savary D, Pouly JL, Wattiez A, Mage G. Ectopic pregnancy: criteria to decide between medical and conservative surgical treatment? J Gynecol Obstet Biol Reprod (Paris) 2003;32(7):S54-63.

6. Lipscomb GH, McCord ML, Stovall TG, Huff G, Portera SG, Ling FW. Predictors of success of methotrexate treatment in women with tubal ectopic pregnancies. N Engl J Med 1999;341 (26):1974-8.

7. Berg CJ, Chang J, Callaghan WM, Whitehead SJ. Pregnancyrelated mortality in the United States, 1991-1997. Obstet Gynecol 2003;101(2):289-96. 
8. Feldkamp M, Carey JC. Clinical teratology counseling and consultation case report: low dose methotrexate exposure in the early weaks of pregnancy. Teratology 1993;47(6):533-9.

9. Stovall TG, Ling FW, Gray LA. Single-dose methotrexate for treatment of ectopic pregnancy. Obstet Gynecol 1991;77(5): 754-7.

10. Nazac A, Gervaise A, Bouyer J, de Tayrac R, Capella-Allouc S, Fernandez H. Predictors of success in methotrexate treatment of women with unruptured tubal pregnancies. Ultrasound Obstet Gynecol 2003;21(2):181-5.

11. American College of Obstetricians and Gynecologists Practice Bulletin No. 94. Medical management of ectopic pregnancy. Obstet Gynecol 2008;111(6):1479-85.

12. Menon S, Colins J, Barnhart K. Establishing a human chorionic gonadotropin cutoff to guide methotrexate treatment of ectopic pregnancy: a systematic review. Fertil Steril 2007;87(3):4814.

13. Nowak-Markwitz E, Michalak M, Olejnik M, Spaczynski M. Cutoff value of human chorionic gonadotropin in relation to the number of methotrexate cycles in the successful treatment of ectopic pregnancy. Fertil Steril 2009;92(4):1203-7.

14. Lipscomb GH, Puckett KJ, Bran D, Ling FW. Management of separation pain after single-dose methotrexate therapy for ectopic pregnancy. Obstet Gynecol 1999;93(4):590-3.

15. Barnhart KT, Gosman G, Ashby R, Sammel M. The medical management of ectopic pregnancy: a meta-analysis comparing "single-dose" and "multidose"regimens. Obstet Gynecol 2003; 101(4):778-84.

16. Adalı E, Kurdoğlu M, Kolusarı A, Yıldızhan R, Çim N, Şahin HG Kliniğimizdeki ektopik gebelik olgularının beş yıllık analizi. J Turk Soc Obstet Gynecol 2010;7(2):139-44.

17. Turhan N, İnegöl İ, Seçkin NC. A three-year audit of the management of ectopic pregnancy. J Turkish German Gynecol Assoc 2004;5(4):310-3.

18. Alkış İ, Mungan T. Diş gebelikte $50 \mathrm{~mm} / \mathrm{m} 2$ IM tek doz methotrexat tedavisi. J Turk Soc Obstet Gynecol 2009;6(3): 211-5.

19. Tawfig A, Agomeya AF, Claman P. Predictors of treatment failure for ectopic pregnancy treated with single - dose methotrexate. Fertil Steril 2000;74(5):877-80.

20. Kimiaei P, Khani Z, Marefian A, Ghavamabadi MG, Salimnejad M. The importance of The Importance of Gestational Sac Size of Ectopic Pregnancy in Response to Single-Dose Methotrexategestational sac size of ectopic pregnancy in response to single- dose methotrexate. ISRN Obstet Gynecol 2013: 269425.

21. Ustunyurt E, Duran M, Coskun E, Ustunyurt ÖB, Şimşek H. Role of initial and day 4 human chorionic gonadotropin levels in predicting the outcome of single-dose methotrexate treatment in women with tubal ectopic pregnancy. Arch Gynecol Obstet 2013;288(5):1149-52.

22. Çelik E, Türkçüoğlu I, Karaer A, Kırıcı P, Eraslan S. Assessment of early decline in percentage of $\beta$-hCG values between days 0 and 4 after methotrexate therapy in ectopic pregnancy for prediction of treatment success. J Turkish German Gynecol Assoc 2013;14(3):125-9.

23. Mungan T, Erdemoğlu E, Guney M. The impact of ultrasonographic impantation site of ectopic pregnancy on methotrexate treatment success and reproductive outcome. J Turkish-German Gynecol Assoc 2007;8(4):387-91. 